\title{
Anthropogenic Impact on the Macrophytes of Pskov Region Alkalitrophic Lakes
}

\author{
D.N. Sudnitsyna \\ Pskov State University; State Research Institute of Lake and River Fisheries
}

\begin{abstract}
In 2007 a research of the macrophytes species composition in three alkalitrophic lakes of Pskov region was conducted with the aim to reveal human impact of experimental activities on Fishery transformation, which were conducted in 1969-1972. The study displayed small changes in higher aquatic plants' composition: the number of macrophytes species almost haven't changed, dominant species of emergent vegetation belt maintained their positions, and locations of species listed in the Red Data Book were unchanged. The strong negative impact fishery activities made only on Charophyta stretches, which has disappeared or their areas were much reduced in studied lakes. One of the reasons of small changes is that the lakes belong to macrophyte type, which are more resistant to anthropogenic influences.
\end{abstract}

Keywords: alkalitrophic lakes, Charophyta, macrophytes.

\section{INTRODUCTION}

Alkalitrophic (alkaline) lakes in Pskov Region were discovered and studied by V.N. Abrosov [1], [2] in the river Velikaya basin (lakes Beloe, Ostrovito, Sinovino et al.).

These lakes are characterized by the following features: the presence of silt containing $\mathrm{CaCO}_{3}$, high transparency of water $(4-8 \mathrm{~m})$, an alkaline reaction of environ, low quantities of oxidation and phytoplankton production. V.N. Abrosov highlights characteristics of alkalitrophic lakes, and emphasizes that "their alkalitrophy is not autochthonous, inherent (by E. Nauman) for lakes located in the limestone basins, but nutrient - the result of Charophyta mass development” [1, p. 308].

Charophyta occupy a relatively small niche in nature, but in areas where the plants exist they have a significant impact on the hydrological regime of water bodies [8], [1]. These algae are able to absorb the water soluble calcium bicarbonate, and insoluble compounds of calcium bicarbonate settle on the algae cell surface. When development of Charophyta is intense these compounds are deposited not only on plants, but also to the bottom of the lake, forming powerful silts [2].

Charophyta are the largest representatives of all freshwater multicellular algae. Their usual height is 20-30 cm, but some plants reach 1-2 $\mathrm{m}$ in height [10]. Partly based on this thesis, Charophyta, as well as aquatic higher plants living in water bodies, are considered to be aquatic macrophytes.

Lakes with a high degree of overgrowing macrophytes are separated into a special type - macrophyte lakes. Eutrophication of such lakes are determined not by production of phytoplankton, but macrophytes production, which are rivals for nutrients, and which accumulate it and hold it in their tissues for a long time during growth process. Phytoplankton in such conditions cannot activate its production functioning [16].

This lakes have been subject to intense human influence since 1968 to 1972, when there have been conducted the experimental fishery activities, which included applying fertilizers and agrochemicals to increase nutrition base and feed supply and "to bring a century character to eutrophy" [3], reduction of native fish species, and planting of valuable fish species juveniles in polyculture [18].

In order to assess the human impact on this rare type of lakes in Pskov Region we examined aquatic plants of lakes Ostrovito, Beloe and Krivoe.

\section{MATERIALS AND METHODS}

Three examined alkalitrophic (macrophytes) lakes (Lake Beloe, Lake Krivoe and Lake Ostrovito) are located in the Alolskaya volost of Pustoshkinsky District.

The lakes are small in size of their surface area (67.5 - 177.3 ha), with an average depth 6.1 - $9.5 \mathrm{~m}$, with high transparency of water $(4-6 \mathrm{~m})$, with medium mineralization, with moderately hard water belonging to hydrocarbonate class of type II calcium group [5]. The lakes are slowly flowing, and are connected into unified hydrological system. Trophic status of these lakes is determined ambiguously: on the basis of hydrochemical parameters they were classified as oligotrophic [5], on the basis of 
phytoplankton - as mesotrophic [13], on the basis of zoobenthos and zooplankton biomass - as eutrophic type [19].

For studying aquatic plants the technique, common in hydrobotany [11] was used.

For assessment of common reed stretches' condition there were used such characteristics as: fertile shoots height, diameter and above-ground shoots biomass.

\section{RESULTS AND DISCUSSION}

The flora and plants of these lakes were first studied in 1966-1968 [6], [7]. In the composition of aquatic plants were identified 54 species of macrophytes, of which Magnoliophyta - 45, Polypdiophyta - 1, Equisetophyta -1, Bryophyta - 2 species, and 5 species of Charophyta: Chara rudis A. Br, Ch. tomentosa L., Ch. jubata A. Br., Chara sp., Nitellopsis obtusa (Desv.) J. Grov. The largest number of macrophyte species was found in Lake Ostrovito - 34, the minimal (21) - in Lake Krivoe, in Lake Beloe were found 30 species [6], [7].

The most prevalent species, which were encountered in all examined lakes, were the following: Phragmites australis (Cav.) Trin. et Steud., Carex rostrata Stokes, C. lasiocarpa Ehrh., Equisetum fluviatile L., Potamogeton natans L., Nuphar lutea (L.) Sibth. et Smith, Nymphaea candida C. Presl, Elodea canadensis (Rich.) Michaux, Chara rudis. They were dominant or co-dominant aquatic plants in studied lakes.

The dominated plants among macrophytes were Charophyta (projective cover degree 90-100\%). They grew to a depth of $6 \mathrm{~m}$ (Lake Ostrovito) and $9 \mathrm{~m}$ (Lake Beloe). Especially prominent role Charophyta played in Lake Ostrovito, where they occupied about $65 \%$ of the macrophytes total area.

In all these lakes aquatic plants were located in zones or belts. There were two dominated belts: the emergent vegetation and submerged vegetation. Among the emergent vegetation open pure stands of Phragmites australis (Lake Ostrovito and Lake Krivoe) or mixed communities of Phragmites and Carex (Lake Beloe) were prominent. Submerged vegetation belt in lakes Beloe and Ostrovito was formed by Charophyta. Air-dry phytomass of macrophytes in Lake Beloe reached $655 \mathrm{~g} / \mathrm{m} 3$, in Lake Ostrovito - $607.3 \mathrm{~g} / \mathrm{m} 3$, which is more than $50 \%$ of the organic matter produced by aquatic plants.

Charophyta were not detected in Lake Krivoe, although earlier Charophyta were found in all lakes, including Lake Krivoe, where "all the bends and bays slopes are covered with stonewort meadows" [4].

In all these lakes in 1969-1972 experimental activities on Fishery transformation were carried out, which includes: destruction of aboriginal and introduction of new fish species, intensive fertilization and artificial eutrophication.
It should be noted that in the early year's fishery measures gave good results. Phytoplankton biomass increased by 5-10 times [14]. Fish production in fertilized lakes increased from 5-15 kg / ha to $300 \mathrm{~kg}$ / ha. At the same time, negative phenomena have been identified: the deterioration of hydrological cycle and hydrochemical regime, the aquatic organisms' productivity reduction after fertilization cessation et al. [18].

Later, a comprehensive analysis of fertilize lakes data showed that 'fertilized lakes' artificial ecosystem existed only as long as the measures were taken" [15]. After the cessation of human impact, as noted D.W. Schindler et al., "the lake slowly or fairly quickly returns to its original state" [20].

From 80-th years of XX century all experimental activities were stopped.

During our research in examined lakes there were discovered 50 species of macrophytes belonging to 29 families. Of these, 1 species was Equisetophyta, 1 Polypdiophyta, 3 species of Bryophyta, 4 species of Charophyta, the rest species (41) were Magnoliophyta.

Comparison with previous researches has shown that number of macrophytes species almost had not changed: as before the first rank in biodiversity has Lake Ostrovito (31), last rank - Lake Krivoe (21), in Lake Beloe there were revealed 28 species.

Dominant species of emergent vegetation belt maintained their positions. Locations of species listed in the Red Data Book Cladium mariscus (L.) Pohl in lakes Ostrovito and Krivoe were unchanged. We discovered another kind of aquatic higher plants from Pskov Region Red Data Book - Najas marina L., which was found in Lake Beloe in Charophyta coenosis.

Some changes in aquatic plants of Lake Ostrovito are associated with a decrease of Elodea sanadensis role, with the emergence of Potamogeton lucens and Potamogeton perfoliatus among dominants, which are forming a small monocoenosis far from the shore, and distribution of Myriophyllum spicatum in the lake. Above-mentioned species was found in the 60s only in the Bay Hodchische, which was separated by dam. In 2007 in this bay Myriophyllum spicatum was almost the only dominant. This species was found in the other two lakes. Propagation of Myriophyllum spicatum usually indicates an increase in the trophic status of the water body [9].

In lakes Krivoe and Ostrovito there was registered a slight expansion of the plants with floating leaves stretches (Nuphar lutea, Nymphaea candida and Potamogeton natans), which may be explained by the presence of a significant number of sites with soils enriched by organic compounds. Typically, these species form mixed communities, which are exposed along the shoreline in stripes or in spots (in Lake Ostrovito its width amounts up to $40 \mathrm{~m}$ ). 
In Lake Krivoe deep-water station $\left(\begin{array}{ll}6 & \mathrm{~m}\end{array}\right)$ Drepanocladus lycopdioides (Schwag.) Warnst. of Bryophyta was detected, whereas it was absent in this lake previously. Mosses tangle also survived in Lake Beloe. According to literature Bryophyta communities fall out from the vegetation composition when water body trophic level is rising. The same happens with the communities in which the main dominant is Potamogeton lucens L. [9]. In the studied lakes this species exists as a co-dominant in submerged plants communities, and in Lake Ostrovito it sometimes forms pure stands at a depth of 1-2.5 m.

Belt type of vegetation arrangement continues to exist in all the lakes. As before two belts dominate: the emersed and submerged vegetation. In 2007, in lakes Ostrovito and Krivoe a belt of coastal aquatic plants consisting of hygrophytes - plants of wetland habitats stood out. In addition to Carex species in the lakes coastal zone were found Agrostis stolonifera L, Lycopus europeus L., Scutellaria galericulata L. et al., apparently caused by decreasing lakes water level in the dry summer in 2006-2007.

The most common overgrowing profiles in 2007 in the studied lakes were: Phragmites australis $\rightarrow$ Nuphar lutea + Nymphaea candida $\rightarrow$ Potamogeton natans; Phragmites australis + Schoenoplectus lacustris $\rightarrow$ Nuphar lutea + Potamogeton natans (lakes Ostrovito and Krivoe); Phragmites australis $\rightarrow$ Schoenoplectus lacustris + Equsetum fluviatile $\rightarrow$ Potamogeton natans $\rightarrow$ Chara rudis (Lake Beloe).

\section{TABLE I}

StRUCTURAL IndicAtors PHRAGMITES AUSTRALIS IN AUGUST 2007 (AVERAGE OF 10)

\begin{tabular}{|l|l|l|l|}
\hline Lakes & $\begin{array}{l}\text { Shoots } \\
\text { height } \\
(\mathrm{cm})\end{array}$ & $\begin{array}{l}\text { Diameter } \\
(\mathrm{cm})\end{array}$ & $\begin{array}{l}\text { Shoots } \\
\text { biomass, g }\end{array}$ \\
\hline Beloe & 135.7 & 0.48 & 12.8 \\
\hline Krivoe & 142.8 & 0.28 & 34.8 \\
\hline Ostrovito & 166.0 & 0.53 & 46.3 \\
\hline
\end{tabular}

The most important dominant of emersed aquatic plant in the studied lakes is Phragmites australis. Literature data and our observations on Lake Peipsi show that with increasing trophic level the structural indicators of this species increase [21]. Previous researchers noted predominance of open, very low yielding common reed, especially in Lake Beloe. Such a situation remains until the present time. Phragmites australis communities in 2007 consisted of thin low yielding reed stands - 4-7 samples/0.25 m2, except Lake Krivoe, where they reached up to 33 / 0.25 m2) (Table. 1)

As it is known, the increase of the water body trophic status via natural or anthropogenic factors leads to changes in species composition and structure of plant communities, to overgrowth areas enlargement.
Absence of significant changes in the higher aquatic plants composition and structure in the studied lakes under artificial eutrophication measures probably is caused by the fact that they belong to the macrophyte type lakes. According to T.N. Pokrovskaya [17], production-functional organization of macrophyte lakes is very stable. "It not only withstands the sharp fluctuations of natural environmental conditions, but also can survive for quite a long time in a conditions markedly disturbed by human impact, when a flow of nutrients into the water greatly increased” [17, p.17].

The specificity of lakes Beloe, Ostrovito and Krivoe is that they are not just macrophyte lakes, but alkalitrophic ones, where the main cenosis role play stonewort algae, which lost this role after anthropogenic interference. In Lake Krivoe, which was subjected to the most severe impact, stonewort algae disappeared even before fertilizer application, immediately after the fishery alteration measures. In Lake Beloe, which was fertilized only once, and fertilizers were applied beyond macrophyte stands, stonewort algae survived better, but only in the coastal area (depth 1-3 m). In Lake Ostrovito fishery activities were not carried out, except for the Bay Hodchische, which is separated by a wooden dam. Eutrophication of this lake occurred as a result of fertilized Lake Beresovoe water discharge via the stream connecting these two lakes. In 2007 in this lake we have revealed only some fragments of stonewort algae in the coastal zone.

\section{CONCLUSIONS}

The study displayed small changes in higher aquatic plants' composition: the number of macrophytes species almost haven't changed, dominant species of emergent vegetation belt maintained their positions, and locations of species listed in the Red Data Book were unchanged.

The strong negative impact fishery activities made only on Charophyta, which has disappeared or their areas were much reduced in studied lakes: in alkalitrophic lakes overgrown area decreased during trophic level increase, and not enlarged. Thus, our research confirms the literature data that lakes eutrophication affects Charophyta development negatively.

\section{REFERENCES}

[1] V.N. Abrosov, "O znachenii zarosley harovyh vodorosley (Charales) v zhizni ozer" (On the significance of stonewort algae (Charales) in lakes’ life), Bot. J., vol. 44, N.5, pp. 684687, 1959.

[2] V.N. Abrosov, “Osnovnye regional'nye cherty ozer istokov rek Volgi, Zapadnoy Dviny, Lovati i Velikoy” (The main regional characteristics of lakes in riverheads of Volga, Zapadnaya Dvina, Lovat' and Velikaya) in Malye vodoemy ravninnyh obblastey SSSR and ih ispol'zovanie (Small water bodies of plain areas of USSR and their use), Moscow, 1961, pp. 305314. 
[3] V.N. Abrosov, N.A. Zabegalina and G.D. Maksimova, “Organizatsia ratsional'nogo rybnogo hozaystva na ozerah Alolskoy eksperimental'noy bazy Pskovskogo otdelenia GosNIORH” (Rational fishery organization in Alol experimental station lakes of GosNIORH Pskov department), GosNIORH Pskov department, Pskov, Rep., 1961.

[4] V.N. Abrosov, "Teoreticheskie predposylki preobrazovania kislovodnyh ozer v evtrofnye” (The theoretical implications of converting oligotrophic lakes into eutrophic ones) in Izvestia GosNIORH (GosNIORH Proc.), vol. 55, 1963, pp. 60-68.

[5] E.A. Afanasiev, "Gidrologo-gidrohomicheskie osobennosti ozer Ostrovito i Krivoe, ispol'zuemyh dlay mnogoletnego vyraschivanya tovarnoy ryby" (Hydrological and hydrochemical features of lakes Ostrovito and Krivoe used for long-term cultivation of marketable fish) in Izvestia GosNIORH (GosNIORH Proc.), vol. 99, 1975, pp. 11-23.

[6] A.P. Belavskaya, "Raspredelenie i produktsia makrofitov v Alol'skih ozerah" (Distribution and production of macrophytes in Alol lakes) in Priroda i hozayastvennoe ispolsovanie ozer Pskovskoy i prilegayuschih oblastey (Nature and utilization of Pskov region and surrounding areas lakes), Pskov, 1971, pp.20-22.

[7] A.P. Belavskaya, N.B. Serafimovich, "Produktsia makrofitov nekotoryh ozer Pskovskoy oblasti” (Macrophytes production in some Pskov region lakes) in Rastitelnye resoursy (Plant resources), vol. 9, N.3, pp.14-21, 1973.

[8] K.V. Dobrohotova, "Harovye vodorosli v tsenozah makrofitov" (Stonewort algae in hydro-macrophytes cenoses) in Trydy Vsesouz. Gidrobil. Ob-va (Proc. Of Hydrobiolog. Soc.), vol. 5, 1953, pp. 258-263.

[9] I.U. Ershov, Fitotsenosistemy ozer Valdaysky vozvyshennosti (Phytocoenosis systems of Valdai Hills Lakes), Rybinsk, 2002, $136 \mathrm{p}$.

[10] M.M. Gollerbah, L.K. Krasavina, Harovye vodorosli: opredelitel presnovodny vodorosley SSSR (Stonewort algae: Identification Reference Guide of the USSR freshwater algae, vol. 14, Leningrad: Nauka, 1983. 183 p.

[11] V.M. Katanskaya, Vyshaya vodnaya rastitelnost kontinentalnyh vodoemov SSSR (Higher aquatic plants of continental water bodies in the USSR), Leningrad: Nauka, 1981. 187 p.

[12] Krasnaya kniga Pskovskoy oblasti (Pskov Region Red Data Book), Pskov, 2014, 543 p.

[13] G.M. Lavrentieva, "Haracteristika mezotrofnogo ozera Krivogo v svayzi s ego ispolzovaniem dlya vyraschivania tovarnoy ryby" (Mesotrophic Lake Krivoe characteristics due to cultivation of marketable fish) in Izvestia GosNIORH (GosNIORH Proc.), vol. 99, 1975, pp. 41-48.

[14] G.M. Lavrentieva, Fitoplankton malyh udobrayemyh ozer (Phytoplankton of small fertilized lakes), Moscow, 1986. 102 p.

[15] G.M. Lavrentieva, “Teoreticheskie osnovy regulirovania ryboproduktivnosti malyh ozer" (The theoretical basis for regulating fish productivity in a small lakes) in Problemy ihtiologii i rybnogo hozayastva: sb. nauch. trudov GosNIORH (Problems of Ichthyology and Fisheries: Proc. Of GosNIORH), N. 336, 2007, pp.189-198.

[16] T.N. Pokrovskaya, "Ustoichivost "makrofitnyh" ozer k antropogennym evtroforuuyschim vozdeystviyam" ("Macrophyte" lakes resistance to anthropogenic eutrophication) in Izv. AN SSSR. Seria geograf. (USSR Acad.Nauk bulletin, Ser. geography), N. 4, pp. 37-46, 1979.

[17] T.N. Pokrovskaya, N.A. Mironova, G.S. Shilkrot, Makrofitnye ozera $i$ ih evtrofirovanie (Macrophyte lake and their eutrophication), Moscow: Nauka, 1983, 152 p.

[18] G.P. Rudenko, "Itogi opytnyh rabot po usovershenstvovaniuy metodov povyshenia ryboproduktivnosti malyh ozer” (Results of experimental work on the methods improvement to increase small lakes fish productivity) in in Izvestia GosNIORH (GosNIORH Proc.), vol. 99, 1975, pp. 257-264.

[19] A.A. Salazkin, "K voprosu o klassifikatsii ozer Pskovskoy oblasty" (On the Pskov Region lakes classification) in Priroda $i$ hozayastvennoe ispolsovanie ozer Pskovskoy i prilegayuschih oblastey (Nature and utilization of Pskov region and surrounding areas lakes), Pskov, pp. 207-209, 1971.

[20] D.W. Schindle et al., Eutrophication in the high arctic Meretta Lake, Corwallis Island (75o lat), in J. Fisheries research Board of Canada, vol. 31, N 5, 1974.

[21] D.N. Sudnitsyna, K.B. Kozyreva, "Bioekologicheskaya i geobotanicheskaya harakteristika trostnika obyknovennogo Pskovsk-Chudskogo ozera” (Bioecological and geobotanical characteristics of Lake Peipsi common reed) in Zapad Rossii $i$ bliznee zarubezie: ustoichvost sotsialno-kulturnyh I ekologohozaystvennyh system: mater. konf., 21-23 noyabra 2005 (West Russia and the CIS countries: sustainability of socio-cultural and ecological and economic systems: conf. 21-23 November, 2005, Pskov: PGPU, 2005, pp.145-148. 